\title{
ŠILDYMO POVEIKIS VYRŲ RAUMENŲ GALINGUMUI IR NUOVARGIUI ATLIEKANT KONCENTRINIUS PRATIMUS
}

\author{
Irina Ramanauskienè ${ }^{1}$, Albertas Skurvydas ${ }^{2}$, Saulè Sipavičiené $\dot{2}^{2}$, Šarūnas Klizas ${ }^{2}$, Laimutis Škikas ${ }^{2}$ \\ Kauno technologijos universitetas ${ }^{1}$, Lietuvos kūno kultūros akademija ${ }^{2}$, Kaunas, Lietuva
}

\begin{abstract}
Irina Ramanauskienè. Kauno technologijos universiteto biomedicinos mokslų daktarè. KTU Kūno kultūros ir sporto centro, Kūno kultūros katedros docentè. Mokslinių tyrimų kryptis - raumenų fiziologija: skirtingos temperatūros poveikis raumenų nuovargiui ir atsigavimui priklausomai nuo lyties ir raumenų susitraukimo greičio.
\end{abstract}

\section{SANTRAUKA}

Tyrimo tikslas - nustatyti, kaip šildymas veikia vyru raumenu galinguma ir nuovargi, atliekant koncentrinius pratimus. Tiriamuju kontingenta sudare $19-23$ metu vyrai $(n=10 ; \bar{u} g i s-177,8 \pm 5,8 \mathrm{~cm}$; kūno masé $-78,2 \pm 6,1 \mathrm{~kg}$, riebalu mase - 7,5\% (5,6 rieb. mase / kg), atrinkti atsitiktinès atrankos metodu. Tiriamieji testuoti izokinetiniu dinamometru „,Biodex Medical System PRO 3“. Prieš šildyma adatiniu termometru buvo matuojama (kontrolinè) vidinè raumenu temperatüra. Registruotas vidutinis raumenu galingumas. Registruojant blauzdos tiesiamuju ir lenkiamuju raumenu rodiklius buvo atliekamas kontrolinis matavimas: 1 serija po 3 judesius (blauzdos tiesimo ir lenkimo) $180^{\circ}$ /s greičiu (prieš krūvi, iš karto po krūvio ir praejus 10, 30, 60 min ir 24 h po jo). Buvo registruojama raumenu maksimalioji valinga jèga, nevalingo susitraukimo jèga, sukelta stimuliuojant elektra $20 \mathrm{ir} 100 \mathrm{~Hz}$ dažniu. Raumenu nevalingo susitraukimo jèga ir maksimalioji valinga jèga buvo registruojama prieš fiziní krūvi, iš karto po krūvio, praejus $20 \mathrm{~min}, 1 \mathrm{~h} 10 \mathrm{~min}$ ir $24 \mathrm{~h}$ po jo. Koncentrinis krūvis (50 blauzdos tiesimu ir lenkimu $180^{\circ}$ / s greičiu) buvo atliekamas didžiausiomis pastangomis. Vidinès raumenu temperatūros matavimo procedūra pakartotinai atlikta iš karto po raumenu pašildymo ir po koncentrinio krūvio.

Po pasyvaus raumenu šildymo vidutinio galingumo rodikliai, tiesiant ir lenkiant koja per kelio sqnarifiksuotu $180^{\circ} / \mathrm{s}$ greičiu, statistiškai patikimai padidejjo, palyginti su kontrolinio tyrimo rezultatais $(p<0,05)$. Nustatytas statistiškai reikšmingas skirtumas tarp kontrolinio tyrimo ir pašildyto raumens nevalingo susitraukimo jègos, sukeltos stimuliuojant elektra 20 ir $100 \mathrm{~Hz}$ dažniu, fiksuojant koja per kelio sanari $135^{\circ}$ ir $90^{\circ} \mathrm{kampu}(\mathrm{p}<0,05)$. Testavimo metu nustatyta, kad vyru pašildytu blauzdos tiesiamuju raumenu vidutinio galingumo nuovargio indeksas didžiausias buvo 41 -50-o susitraukimo metu. Vidine raumenu temperatūra po 45 min šildymo $\left(39,5 \pm 0,2^{\circ} \mathrm{C}\right)(p<0,001)$ reikšmingai pakito, palyginti su pradine (prieš šildyma $-36,9 \pm 0,1^{\circ} \mathrm{C}$ ). Atlikus koncentrini krūvĭ, šildyto raumens vidinè temperatüra reikšmingai padidèjo iki $40,1 \pm 0,1^{\circ} \mathrm{C}$.

Tyrimu nustatyta, kad pasyvus šildymas padidino vidutini raumenu galinguma ir nevalingo susitraukimo jèga, sukelta stimuliuojant elektra 20 ir $100 \mathrm{~Hz}$ dažniu (esant skirtingam raumens ilgiui, t. y. fiksuojant koja per kelio sqnari $135^{\circ}$ ir $90^{\circ}$ kampu). Visgi atliekant koncentrinị krūvį vidutiniu greičiu pasyvus šildymas atsparumo nuovargiui nepaveikè.

Raktažodžiai: pasyvus šildymas, galingumas, raumenujejga, koncentrinis krūvis, nuovargis.

\section{IVADAS}

$\mathrm{T}$ emperatūra yra svarbus veiksnys, nustatantis kontraktilinius ir metabolinius griaučių raumenų procesus (Ranatunga, 1998). Tiesioginis galūnių pašildymas gali smarkiai paveikti raumenų jègą ir galingumą koncentriniu pratimu metu (Sargeant, 1987; Ball et al., 1999). Pakilus raumenų temperatūrai, sausgyslès, raiščiai ir jungiamasis audinys daugiau išsitem- pia, dèl to padidèja judesių amplitudè per sąnari (Kirkendall, Garrett, 2002). Temperatūra smarkiai veikia žmogaus griaučių raumenų funkciją (Ball et al., 1999). Ši termini priklausomumą rodo raumenų molekulinè sandara. Pašildžius raumeni, paspartejja ATP hidrolizè (Ball et al., 1999) ir anaerobinè glikolizè (Febbraio, 2000). Skersiniu miozino tiltelių sukibimas su aktinu ir 
atsipalaidavimas pagreitèja dèl spartesnès ATP hidrolizès (Ball et al., 1999) ir $\mathrm{Ca}^{2+}$ kinetiniu ypatybiu (Ichihara, 1998). Manoma, kad raumenų galingumo pagerèjimą po pašildymo lemia padidejęs raumenų susitraukimo greitis (Davies, Young, 1983). Pakilusi raumenų temperatūra pirmiausia suaktyvina metabolinius procesus, padidina deguonies atsiskyrimą nuo hemoglobino ir mioglobino, pagreitina kraujo tekejjimo srovę raumenyse, sumažina raumenų klampumą (Booth et al., 2001). A. J. Sargeant (1987) nustate, kad temperatūros pakeitimas didina raumenų jègą ir galingumą (sukant veloergometrą jèga ir galingumas padidedavo $4 \%$, kai raumenų temperatūra būdavo padidinama $1^{\circ} \mathrm{C}$ ). Tiriant didžiausio intensyvumo fiziniu pratimų, atliekamu karščio sąlygomis, poveiki tiriamajam (kai aplinkos temperatūra $-34^{\circ} \mathrm{C}$ ) buvo nustatyta: palyginti su normalia aplinka (kai temperatūra $-20^{\circ} \mathrm{C}$ ), maksimalusis galingumas padideja daugiausia $8 \%$ (Falk et al., 1998). Todèl šio tyrimo tikslas nustatyti, kaip šildymas veikia vyrų raumenu galingumą ir nuovargi, atliekant koncentrinius pratimus. Raumeniui nuvargus, sutrinka nervo raumens sinapsès veikla, veikimo potencialo sklidimas $\mathrm{T}$ sistema, mažeja $\mathrm{Ca}^{2+}$ išsiskyrimo iš sarkoplazminio tinklo greitis ir kiekis, letėja ATP hidrolizè ir resintezè (Fitts, 1994), daugèja vandenilio jonų ir neorganinio fosfato (Sahlin et al., 1998), dèl to mažèja aktino ir miozino tilteliu sukibimo jèga ir greitis, miofibriliu jautrumas kalcio jonams (Westerblad, Allen, 2002). Pasak M. A. Febbraio (2000), padidejusi raumenų temperatūra susilpnina griaučių raumenų veiklą, medžiagų apykaita, ir tai sukelia nuovargi. B. Drust ir kt. (2005) nustatè, kad padidejjusi raumenu temperatūra pagerino sprinterio rezultatą, tačiau pakartojus krūvi darbo galingumas dèl hipertermijos sumažèjo. Hipotezè - spèjame, kad prieš krūvị pašildytas raumuo padidins raumenu jęgą, tačiau sumažès raumenų atsparumas nuovargiui.

\section{TYRIMO METODAI}

Tiriamuju kontingentą sudare 19-23 metu vyrai $(\mathrm{n}=10$; ūgis $-177,8 \pm 5,8 \mathrm{~cm}$; kūno masè $-78,2 \pm 6,1 \mathrm{~kg}$, riebalu mase $-7,5 \%$ $(5,6$ rieb. mase $/ \mathrm{kg}))$. Tyrimas atliktas laikantis $1975 \mathrm{~m}$. Helsinkio deklaracijoje priimtu principu dèl žmonių eksperimentų etikos. Tyrimo protokolas aptartas ir patvirtintas Kauno regioniniame biomedicininiu tyrimu etikos komitete (protokolo Nr. P1-80/2004).
Blauzdos tiesiamųjų ir lenkiamųjų raumenų savybių testavimas. Tiriamieji buvo testuojami „Biodex Medical System PRO 3“ (sertifikuota ISO 9001 EN 46001) - žmogaus raumenų testavimo ir reabilitacijos aparatūra. Prie dinamometro pritvirtinamas papildomas blauzdos tvirtinimo itaisas. $\mathrm{Nu}-$ statoma kelio anatominè sąnario ašis ir sulyginama su dinamometro dinaminès apkrovos mazgo ašimi. Nustatoma visa kelio sąnario amplitude (blauzdą ištiesus $0^{\circ}$ ir sulenkus $115^{\circ} \mathrm{kampu}$ ). Mažinant viso kūno inercini svyravimą, tiriamasis apjuosiamas pečiu, liemens ir šlaunies diržais. Blauzda sutvirtinama diržu virš kulnakaulio gumburo ties apatiniu trečdaliu, koja fiksuojama per kelio sąnari $90^{\circ}$ ir $60^{\circ} \mathrm{kampu}$, pasveriama tada, kai ji fiksuota $72 \pm 5^{\circ}$ kampu (gravitacinès sunkio jègos momentu). Valdymo skyde pasirenkamas izokinetinis režimas ir koncentrinis susitraukimo tipas. Registruotas vidutinis raumenu galingumas.

Keturgalvio šlaunies raumens susitraukimo savybių testavimas. Keturgalvis šlaunies raumuo buvo stimuliuojamas elektros stimuliatoriaus (MG 440, Medicor) dviem paviršiniais elektrodais $(9 \times 18 \mathrm{~cm})$. Raumuo dirginamas stačiakampès formos elektriniu impulsu. Impulso trukmè $-1 \mathrm{~ms}$, stimuliavimo itampa parinkta tokia, kad sukeltu didžiausią raumenų susitraukimo jègą (nuo 120 iki $150 \mathrm{~V}$ ). Prieš mènesi vieną kartą buvo atliekamas bandomasis raumenų stimuliavimas ir parenkama didžiausia pakeliama ittampa (Skurvydas et al., 2002). Jègos signalas buvo apdorojamas kompiuteriu, pastaruoju taip pat valdomi ir stimuliavimo režimai. Buvo registruojama raumenų jèga, sukelta stimuliuojant juos elektra $20 \mathrm{~Hz}$ (P 20) ir $100 \mathrm{~Hz}$ (P 100) dažniu. Raumenų nevalingo susitraukimo jèga (P) ir maksimalioji valinga jèga (MVJ) buvo registruojama prieš fizinị krūvị, iš karto po krūvio, praejus $20 \mathrm{~min}, 1 \mathrm{~h} 10 \mathrm{~min}$ ir $24 \mathrm{~h}$ po jo.

Raumenų pasyvaus šildymo metodika. Tiriamieji sédėdami ištiestas kojas 45 minutes laiké šiltoje vonioje, kurios vandens temperatūra $44 \pm 1{ }^{\circ} \mathrm{C}$, kambario temperatūra $-20-22^{\circ} \mathrm{C}$. Vandens i vonia buvo pripilama tiek, kad šlaunys būtų visiškai panardintos vandenyje. Šildymo pabaigoje raumenų temperatūra $3 \mathrm{~cm}$ gylyje padidejo $\sim 2,7^{\circ} \mathrm{C}$ (Sargeant, 1987; Ramanauskienè ir kt., 2006). Vandens temperatūra buvo matuojama vandens termometru, patalpos - oro termometru.

Vidinès raumenų temperatūros matavimo metodika. Vidinè raumenu temperatūra (pradinè ir iš karto po raumenu šildymo) buvo matuojama adatiniu termometru (Ellab A / S, tipas DM 852, Danija). Dūrio vieta dezinfekuojama 5\% spiritiniu 
jodo tirpalu. İduriama į šoninio plačiojo šlaunies raumens (vastus lateralis) vidurini trečdali $(3 \mathrm{~cm}$ gilumu), šone nuo šlaunikaulio. Adatinis termometras po kiekvieno panaudojimo sterilizuojamas autoklave (gamintojas: M.O.COM Via delle Azlee 1, 20090 Buccinaso, Italija). Sterilizacijos proceso laikas $-30 \mathrm{~min}$, temperatūra $-121^{\circ} \mathrm{C}$.

Tyrimo eiga. Iš viso atlikti du eksperimentai: kontrolinis tyrimas (kai raumuo buvo iprastinès temperatūros) ir pašildyto raumens (kai raumens vidinè temperatūra padidinta iki $39,5 \pm 0,3^{\circ} \mathrm{C}$ ). Tarp tyrimų daryta ne mažesnè kaip mėnesio pertrauka. Visų eksperimentų eiga buvo ta pati. Tiriamieji prieš kiekvieną eksperimentą buvo supažindinami su jo eiga ir mokomi atlikti testą. Kambario temperatūra viso tyrimo metu buvo pastovi (20$22^{\circ} \mathrm{C}$ ). Prieš šildymą adatiniu termometru buvo matuojama (kontrolinè) vidinė raumenu temperatūra. Registruotas vidutinis raumenų galingumas. Registruojant blauzdos tiesiamuju ir lenkiamuju raumenu rodiklius, buvo atliekamas kontrolinis matavimas: 1 serija po 3 judesius (blauzdos tiesimo ir lenkimo) $180^{\circ} / \mathrm{s}$ greičiu (prieš krūvị, iš karto po krūvio, praėjus 10, 30, 60 min ir $24 \mathrm{~h}$ po jo). Tyrimo metu buvo registruojama raumenu maksimalioji valinga jèga, nevalingo susitraukimo jèga, sukelta stimuliuojant elektra 20 ir $100 \mathrm{~Hz}$ dažniu. Raumenų nevalingo susitraukimo jèga (P) ir maksimalioji valinga jèga (MVJ) buvo registruojama prieš fizini krūvị, iš karto po krūvio, praejus $20 \mathrm{~min}, 1 \mathrm{~h} 10 \mathrm{~min}$ ir $24 \mathrm{~h} 10 \mathrm{~min}$ po jo. Koncentrinis krūvis (50 blauzdos tiesimų ir lenkimų $180^{\circ} / \mathrm{s}$ greičiu) buvo atliekamas didžiausiomis pastangomis. Vidinès raumenų temperatūros matavimo procedūra pakartotinai atlikta iš karto po raumenų šildymo ir po koncentrinio krūvio.
Statistiniai skaičiavimai. Tyrimo duomenys analizuoti aprašomosios ir sudètingesnès statistinès analizès metodais naudojant programinius Microsoft ${ }^{\circledR}$ Excel 2003 ir SPSS paketus. Apdorojant tyrimu duomenis apskaičiuotas aritmetinis vidurkis, standartinis nuokrypis. Tiriamujų skirtingos temperatūros vidurkių skirtumo statistiniam reikšmingumui ịvertinti naudotas dviejų veiksnių dispersinès analizès modelis. Skirtumas statistiškai reikšmingas, kai $\mathrm{p}<0,05$.

Nuovargio indeksas apskaičiuojamas pagal formulę:

$$
\begin{aligned}
& \mathrm{NI}=\frac{\operatorname{Pr}_{.(1-3 \text { vid. })}-\text { Gal. }(8-10 \text { vid. })}{\operatorname{Pr} .(1-3 \text { vid. })} \times 100 \\
& \mathrm{NI}=\frac{\operatorname{Pr}_{(}(1-3 \text { vid. })-\text { Gal. }(48-50 \text { vid. })}{\operatorname{Pr} .(1-3 \text { vid. })} \times 100,
\end{aligned}
$$

čia Pr. (1-3 vid.) - matavimo imties pirmo-trečio duomens vidurkis; Gal. (8-10 vid.) — matavimo imties aštunto-dešimto duomens vidurkis ir t. t.; Gal. (48-50 vid.) - matavimo imties keturiasdešimt aštunto-penkiasdešimto duomens vidurkis.

\section{REZULTATAI}

Pašildyto raumens nevalingo susitraukimo jëga (P), sukelta stimuliuojant elektra 20 ir $100 \mathrm{~Hz}$ dažniu (esant skirtingam raumens ilgiui, t. y. fiksuojant koją per kelio sąnari $135^{\circ}$ ir $\left.90^{\circ} \mathrm{kampu}\right)$ po abiejų fizinių krūvių per $24 \mathrm{~h}$ (palyginti su pradiniais rodikliai) atsigavo iki pradinio lygio (1, 2 pav.).

Nustatytas statistiškai reikšmingas rodikliu skirtumas tarp kontrolinio tyrimo (KT) ir pašildyto raumens nevalingo susitraukimo jègos, sukel-

\begin{abstract}
1 pav. Raumenų nevalingo susitraukimo, sukelto stimuliuojat $20 \mathrm{~Hz}$ dažniu (kai raumuo $135^{\circ}$ ir $90^{\circ} \mathrm{kampu}$ ) jègos reikšmių kitimas prieš krūvị, iš karto po krūvio (Ak), praèjus 20 (A 20), 1 h 10 min (A 70) ir $24 \mathrm{~h}$ (A 24) po jo
\end{abstract}

Pastaba. * $-\mathrm{p}<0,05-$ nevalingas raumenų susitraukimas reikšmingai pakito, palyginti su reikšme prieš krūvị; $£-p<0,05-$ kontrolinio tyrimo metu ir pašildyto raumens jègos pokyčio skirtumas.

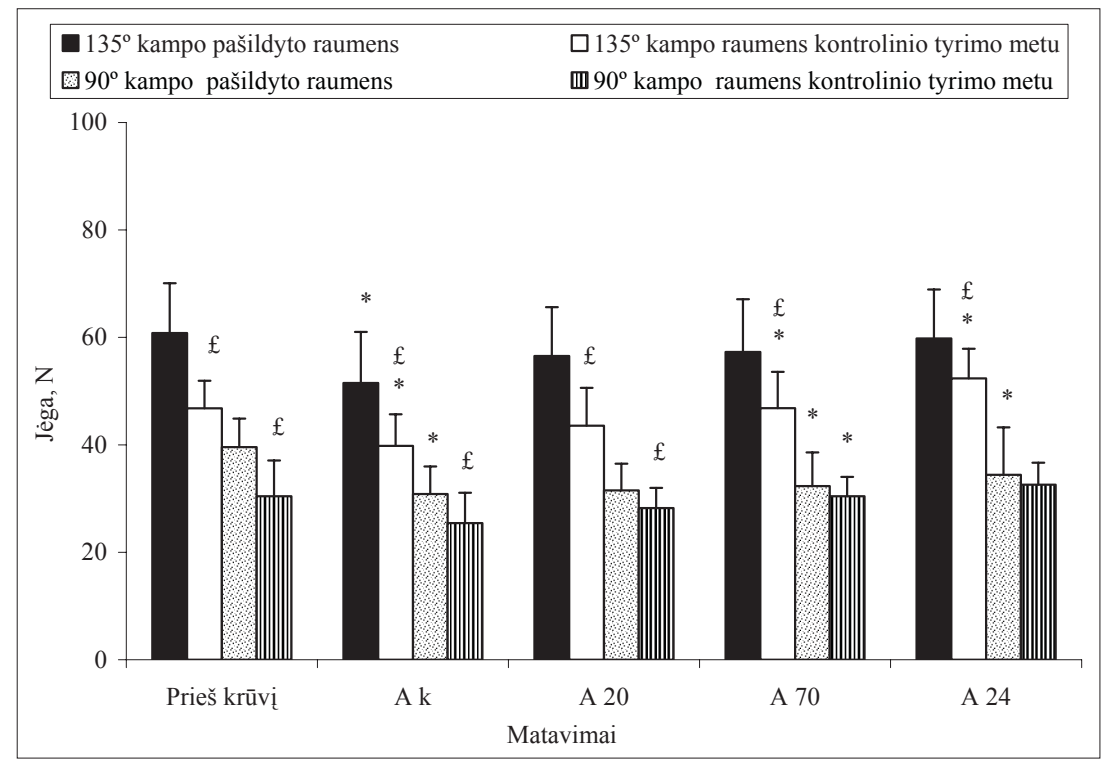



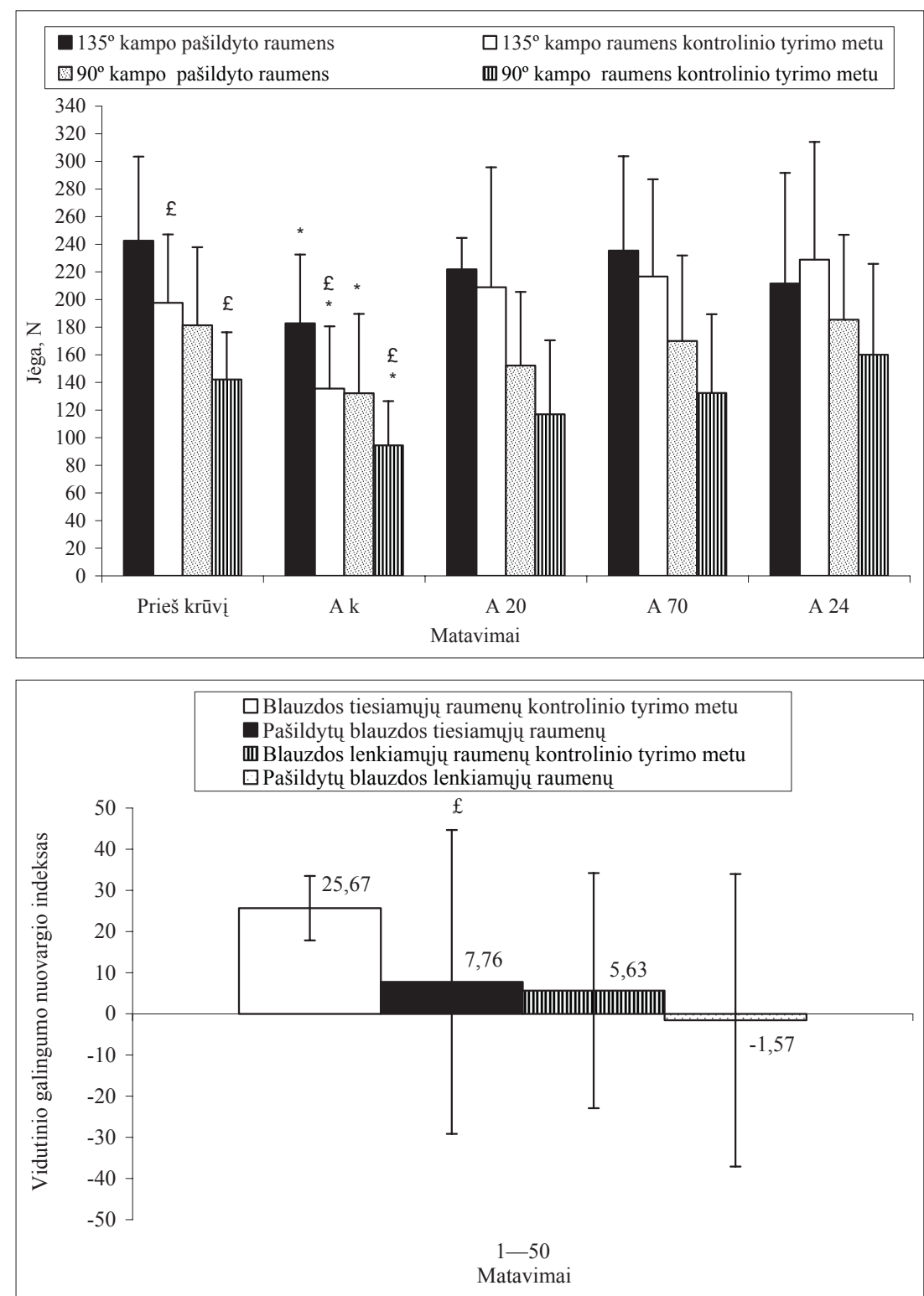

2 pav. Raumenų nevalingo susitraukimo, sukelto stimuliuojat $100 \mathrm{~Hz}$ dažniu (kai raumuo $135^{\circ}$ ir $\left.90^{\circ} \mathrm{kampu}\right)$ jègos reikšmių kitimas prieš krūvị, iš karto po krūvio (Ak), praèjus 20 (A 20), 1 h 10 min (A 70) ir 24 h (A 24) po jo
Pastaba. * - p $<0,05$ - nevalingas raumenų susitraukimas reikšmingai pakito, palyginti su reikšme prieš krūvị; $£$ - $p<0,05-$ kontrolinio tyrimo metu ir pašildyto raumens jègos pokyčio skirtumas.

3 pav. Vidutinio galingumo nuovargio indeksas $1-50$ raumenu susitraukimo metu (\%) tiesiant ir lenkiant koją per kelio sąnari fiksuotu $180^{\circ}$ / s greičiu
Pastaba. $£-p<0,05$ - kontrolinio tyrimo metu ir pašildyto raumens vidutinio galingumo pokyčio skirtumas. tos stimuliuojant elektra 20 (1 pav.) bei $100 \mathrm{~Hz}$ (2 pav.) dažniu ir fiksuojant koją per kelio sąnari $135^{\circ}$ ir $90^{\circ} \mathrm{kampu}(\mathrm{p}<0,05)$. Dviejų veiksnių dispersinè analizė atskleide, kad analizuojamu jègos rodiklių pokytis stimuliuojant raumeni $20 \mathrm{~Hz}$ dažniu priklausè nuo temperatūros $(\mathrm{p}<0,041)$, tačiau ryšio tarp laiko ir vertinamos raumenu būsenos nenustatėme $(\mathrm{p}>0,05)(1 \mathrm{pav}$.$) .$

Po pasyvaus raumenu šildymo vidutinio galingumo rodikliai tiesiant (pašildyto raumens $116,18 \mathrm{~W}$, kontrolinio tyrimo $-75,04 \mathrm{~W}$ ) ir lenkiant (pašildyto raumens $-67,66 \mathrm{~W}$, kontrolinio tyrimo - 57,77 W) koją per kelio sąnari fiksuotu $180^{\circ} / \mathrm{s}$ greičiu statistiškai patikimai padidèjo, palyginti su kontrolinio tyrimo reikšmèmis $(\mathrm{p}<0,05)$.

Nustatytas vidutinio galingumo nuovargio indekso (NI) (nuo 1 iki 50 raumenų susitraukimo) statistiškai reikšmingas skirtumas tarp vyrų kon- trolinio tyrimo ir pašildytų blauzdos tiesiamuju raumenų rodiklių $(\mathrm{p}<0,05)$. Pašildytų blauzdos tiesiamuju raumenų vidutinio galingumo nuovargio indeksas statistiškai reikšmingai didesnis ( $\mathrm{p}<0,05)$ (3 pav.).

Testavimo metu nustatyta, kad vyru pašildytų blauzdos tiesiamujų raumenų vidutinio galingumo nuovargio indeksas (NI) didžiausias $41-50$-o susitraukimo metu, kontrolinio tyrimo - 31-40-o susitraukimo metu (4 pav.). Blauzdos lenkiamuju raumenu NI: pašildytų - 31-40-o susitraukimo metu, kontrolinio tyrimo - 21-30-o susitraukimo metu (4 pav.). Vyrų blauzdos tiesiamujų ir lenkiamujų raumenų NI skirtumas yra reikšmingas tarp pašildytų raumenų ir kontrolinio tyrimo $21-30$-o susitraukimo rodikliu $(\mathrm{p}<0,05)$ (4 pav.). Vyrų vidutinio galingumo nuovargio indeksas tiesiant koją per kelio sąnarị fiksuotu $180^{\circ} / \mathrm{s}$ greičiu priklauso nuo laiko $(\mathrm{p}<0,031)$ ir temperatūros 
4 pav. Vidutinio galingumo nuovargio indeksas (\%) tiesiant ir lenkiant koją per kelio sąnarị fiksuotu $180^{\circ} / \mathrm{s}$ greičiu
Pastaba. $£-p<0,05-$ kontrolinio tyrimo metu ir pašildyto raumens vidutinio galingumo pokyčio skirtumas.

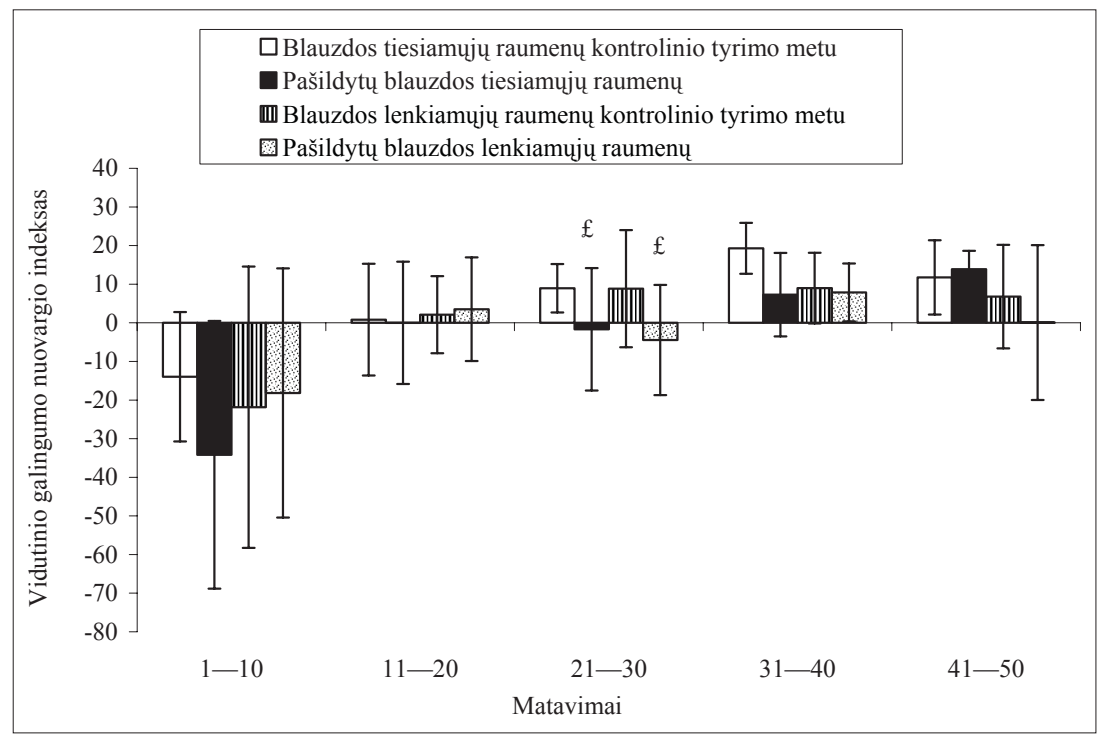

$(\mathrm{p}<0,004)$ - ryšys reikšmingas $(\mathrm{p}<0,017)$. Lenkiant koją per kelio sąnari fiksuotu $180^{\circ} / \mathrm{s}$ greičiu, NI priklauso nuo laiko $(\mathrm{p}<0,022)$. Tarp laiko ir temperatūros rodiklių $(\mathrm{p}<0,002)$ nustatytas reikšminga ryšys (4 pav.).

Vidinè raumenų temperatūra po 45 min šildymo $\left(39,5 \pm 0,2^{\circ} \mathrm{C}\right)$ reikšmingai pakito, palyginti su pradine reikšme (prieš šildymą $-36,9 \pm 0,1^{\circ} \mathrm{C}$ ) $(\mathrm{p}<0,001)$. Atlikus koncentrini krūvị, pašildyto raumens vidinè temperatūra reikšmingai padidejo iki $40,1 \pm 0,1^{\circ} \mathrm{C}(\mathrm{p}<0,05)$.

\section{REZULTATŲ APTARIMAS}

Iškelta hipotezè pasitvirtino iš dalies. Tyrimo duomenys parodè, kad šildymas padidino vidutini raumenu galingumą ir nevalingo susitraukimo jègą, sukeltą stimuliuojant elektra 20 ir $100 \mathrm{~Hz}$ dažniu. Visgi pasyvus šildymas nesumažino atsparumo nuovargiui, atliekant koncentrini krūvi vidutiniu greičiu.

Pasyvus šildymas padidino vidutini raumenu galingumą ir nevalingo susitraukimo jègą, sukeltą stimuliuojant elektra 20 ir $100 \mathrm{~Hz}$ dažniu (esant skirtingam raumens ilgiui, t. y. fiksuojant koją per kelio sąnarị $135^{\circ}$ ir $90^{\circ} \mathrm{kampu}$ ). Panašu šildymo poveikị raumens susitraukimo savybėms nustate ir kiti mokslininkai (Davies, Young, 1983; Bružas ir kt., 2003; Bružas, 2004; Linnane et al., 2004). Pakilus raumenų temperatūrai paspartejja ATP hidrolizè (Ball et al., 1999) ir anaerobinè glikolizè (Febbraio, 2000). Manoma, kad raumenu galingumo pagerejjimą po šildymo lemia padidejęs raumenų susitraukimo greitis (Davies, Young, 1983; Bružas, 2004). Skersinių miozino tiltelių sukibimas su aktinu ir atsipalaidavimas pasparteja dèl pagreitejusios ATP hidrolizès (Ball et al., 1999) ir $\mathrm{Ca}^{2+}$ kinetiniu ypatybiu (Ichihara, 1998). E. Kandratavičius ir kt. (2003) nustate, kad po raumenų pašildymo maksimalusis BKMC (bendrojo kūno masès centro) greitis atsispyrimo metu buvo didesnis $(\mathrm{p}<0,05)$ nei normaliomis salygomis (atitinkamai 2,64 $\pm 0,03$ ir 2,57 $\pm 0,04 \mathrm{~m} / \mathrm{s}$ ). Maksimalusis santykinis atsispyrimo galingumas pasyviai pašildžius raumeni, palyginti su atsispyrimo galingumu normaliomis sąlygomis, statistiškai patikimai nepadidejo (atitinkamai 292,83 $\pm 28,99$ ir $274,87 \pm 18,74 \mathrm{~W} / \mathrm{kg}$; p > 0,05). Amortizuojamojo pritūpimo šuolio aukštis po šildymo buvo didesnis $(p<0,05)$ nei šokant normaliomis sąlygomis (atitinkamai 36,02 $\pm 0,65$ ir 34,14 $\pm 1,17 \mathrm{~cm}$ ). Mokslininkai nustate, kad padidejjusi raumenu temperatūra nevienareikšmiškai veikia amortizuojamojo pritūpimo šuolio biomechanines ypatybes (Kandratavičius ir kt., 2003). D. M. Linnane ir kt. (2004) nustatè, kad pašildžius raumenis $43^{\circ} \mathrm{C}$ vandens temperatūros vonioje (14 min) reikšmingai padideja galingumas (iprastinès temperatūros raumens - $990 \mathrm{~W}$, pašildyto - $1057 \mathrm{~W})$, krūvi atliekant veloergometru (maksimaliu intensyvumu) koncentriniu režimu. V. Bružas ir kt. (2003) nustaté, kad keturgalvio šlaunies raumens temperatūros pakèlimas apie $2,7^{\circ} \mathrm{C}$ reikšmingai padidina raumenų mažų ir didelių stimuliavimo dažnių sukeltą jègą bei atsipalaidavimo greití. Pašildžius kojų raumenis, reikšmingai padidejja keturgalvio šlaunies raumens nevalingo izometrinio susitraukimo jèga (išskyrus $10 \mathrm{~Hz}$ sukeltą jègą), atsipalaidavimo iki pusès jègos greitis, veloergometro mynimo galingumas ir šuolio aukštis, o maksimalioji valinga jèga nepakinta. Atliekant $30 \mathrm{~s}$ trukmès krūvị veloergometru maksimaliu intensyvumu 
(Vingeito testą) padideja veloergometro mynimo galingumas, bet sumažėja raumenų atsparumas nuovargiui (Bružas, 2004).

Tyrimo rezultatai rodo, kad pasyvus šildymas nesumažino atsparumo nuovargiui, atliekant koncentrinį krūvị vidutiniu greičiu. Tiek pašildytų raumenų, tiek kontrolinio tyrimo rodikliai panašūs. Padidèjęs neorganinio fosfato kiekis yra svarbiausias veiksnys griaučiu raumenų nuovargio metu (Westerblad, Allen, 2002). Eksperimentai parode, kad neorganinio fosfato gausėjimas mažina skersiniu tilteliu jègą (Gordon et al., 2000; Dahlstedt, Westerblad, 2001), slopina $\mathrm{Ca}^{2+}$ perkèlimą iš sarkoplazminio tinko (Duke, Steele, 2000). Neorganinis fosfatas per raumens susitraukimą gali sulètinti $\mathrm{Ca}^{2+}$ atsipalaidavimą iš sarkoplazminio tinklo ir taip sumažinti laisvuju $\mathrm{Ca}^{2+}$ kiekị, reikalingą raumeniui atsipalaiduoti (Dahlstedt, Westerblad, 2001). Aukšta aplinkos (Galloway, Maughan, 1997) ir padidejusi vidinè organizmo temperatūra (Gonzalez-Alonso et al., 1999) pagreitina nuovargio atsiradimą, atlie- kant didelio intensyvumo pratimus. Atlikto tyrimo duomenys sutampa su V. Bružo ir kt. (2003) gautaisiais - šildymas neturi poveikio maksimaliosios valingos jègos, mažų ir didelių stimuliavimo dažniu sukeltos jègos, atsipalaidavimo greičio nuovargiui. E. Kandratavičius (2004) nustaté, kad pasyvus raumenų šildymas prieš atliekant maksimalaus intensyvumo kartotinius ekscentrinius-koncentrinius pratimus nepakeitè raumenu nemetabolinio nuovargio indikatoriu - maksimaliosios valingos jègos ir mažų stimuliavimo dažnių sumažèjimo, ypač raumeniui esant mažo ilgio, užregistruoto iš karto po krūvio.

\section{IŠVADOS}

Pasyvus šildymas padidino vidutini galingumą ir nevalingo raumenų susitraukimo jègą, sukeltą stimuliuojant elektra 20 ir $100 \mathrm{~Hz}$ dažniu. Visgi pasyvus šildymas koncentrinio krūvio metu atsparumo nuovargiui nepaveikè.

\section{LITERATŪRA}

Ball, D., Burrows, C., Sargeant, A. J. (1999). Human power output during repeated sprint cycle exercise: The influence of thermal stress. European Journal of Applied Physiology, 79, 360-366.

Booth, J., Wilmore, B. R., Macdonald, A. D. et al. (2001). Whole-body pre-cooling does not alter human muscle metabolism during sub-maximal exercise in the heat. European Journal of Applied Physiology, 84, 587-590.

Bružas, V., Skurvydas, A., Lukošiūtè, I., Rudas, E. (2003). Šildymo poveikis raumens nuovargiui ir atsigavimui. $U g$ dymas. Kūno kultūra. Sportas, 2 (47), 15-25.

Bružas, V. (2004). Šildymo poveikis raumens funkcijai, nuovargiui ir atsigavimui maksimalaus intensyvumo fizinio krūvio metu ir po jo: biomedicinos m. daktaro disertacija. Kaunas: KMU.

Dahlstedt, A. J., Westerblad, H. (2001). Inhibition of creatine kinase reduces the rate of fatigue - induced decrease in tetanic $\left[\mathrm{Ca}^{2+}\right]$ in mouse skeletal muscle. Journal of Physiology (London), 533, 639-649.

Davies, C. T. M., Young, K. (1983). Effects of temperature on the contractile properties and muscle power of triceps surae in humans. Journal of Applied Physiology, $55,191-195$.

Drust, B., Rasmussen, P., Mohr, M., Nielsen, B., Nybo, L. (2005). Elevations in core and muscle temperature impairs repested sprint performance. Acta Physiologica Scandinavica, 183, 181-90.

Duke, A. M., Steele, D. S. (2000). Characteristics of phosphate-induced $\mathrm{Ca}^{2+}$ efflux from the SR in mechanically skinned rat skeletal muscle fibers. American Journal of Physiology. Cell Physiology, 278, C126-135.

Falk, B., Radom-Isaac, S., Hoffman, J. R. et al. (1998). The effects of heat exposure on performance of and recovery from high-intensity, intermittent exercise. International Journal of Sports Medicine, 19, 1-6.
Febbraio, M. A. (2000). Does muscle function and metabolism affect exercise perfomance in the heat? Exercise and Sport Science Reviews, 28, 171-176.

Fitts, R. H. (1994). Cellular mechanisms of muscle fatigue. Physiological Review, 7, 49-95.

Galloway, S. D. R. and Moughan, R. J. (1997). Effects of ambient temperature on the capacity to perform prolonged exercise in humans. Medicine and Science in Sports and Exercise, 29, 1240-1249.

Gonzalez-Alonso, J., Teller, C., Anderson, S. L. et al. (1999). Influence of body temperature on the development of fatigue during prolonged exercise in the heat. Journal of Applied Physiology, 86, 1032-1039.

Gordon, A. M., Homsher, E., Regnier, M. (2000). Regulation of contraction in striated muscle. Physiological Review, 80, 853-924.

Ichihara, Y. (1998). Effect of temperature on $\mathrm{Ca}$ induced Ca release (CICR) rate. Masui, 47 (3), 281-285.

Kandratavičius, E., Skurvydas, A., Lukošiūtè, I. (2003). Temperatūros poveikis šuolio be amortizuojamojo pritūpimo kinematiniams rodikliams. Ugdymas. Küno kultūra. Sportas, 4 (49), 8-14.

Kandratavičius, E. (2004). Šildymo poveikis žmogaus koju raumenu susitraukimo ir atsipalaidavimo savybems priklausomai nuо raumenu darbo režimo ir struktūrinio nuovargio: biomedicinos $m$. daktaro disertacija. Kaunas: KMU.

Kirkendall, D. T. and Garret, W. E. (2002). Clinical perspectives regarding eccentric muscle injury. Clinical Orthopaedics and Related Research, 403, 81-89.

Linnane, D. M., Bracken, R. M., Brooks, S., Cox, V. M., Ball, D. (2004). Effects of hypertermia on the metabolic responses to reapeated high-intensity exercise. European Journal of Applied Physiology, 93, 159-166.

Ramanauskienė, I., Skurvydas, A., Brazaitis, M. ir kt. 
(2006). Moterų ir vyrų kelio tiesiamujų ir lenkiamujų raumenų susitraukimo funkcijos priklausomybè nuo temperatūros. Ugdymas. Kūno kultūra. Sportas, 3 (62), 49-55.

Ranatunga, K. W. (1998). Temperature dependence of mechanical power output in mammalian (rat) skeletal muscle. Experimental Physiology, 83, 371-376.

Sahlin, K., Tonkonogi, M., Söderlund, K. (1998). Energy supply and muscle fatigue in humans. Acta Physiologica Scandinavica, 162, 261-266.

Sargeant, A. J. (1987). Effect of muscle on leg extension force and short-term power output in humans. European Journal of Applied Physiology, 56, 693-698.

Skurvydas, A., Dudoniene, V., Kalvenas, A., Zuoza, A. (2002). Skeletal muscle fatigue in long-distance runners, sprinters and untrained men after repeated drop jumps performed at maximal intensity. Scandinavian Journal of Medicine and Science in Sports, 12, 34-39.

Westerblad, H., Allen, D. G. (2002). Recent advances in the understanding of skeletal muscle fatigue. Current Opinion in Rheumatology, 14 (6), 648-652.

\title{
EFFECT OF WARMING ON THE SKELETAL MUSCLE POWER AND FATIGUE FOR MEN PERFORMING CONCENTRIC EXERCISE
}

\author{
Irina Ramanauskiené $\dot{e}^{1}$, Albertas Skurvydas ${ }^{2}$, Saulè Sipavičien $\dot{e}^{2}$, \\ Šarūnas Klizas ${ }^{2}$, Laimutis Škikas ${ }^{2}$ \\ Kaunas University of Technology', Lithuanian Academy of Physical Education ${ }^{2}$, \\ Kaunas, Lithuania
}

\begin{abstract}
The aim of the present study was to establish the effect of warming on the skeletal muscle power and fatigue of men performing concentric exercise. Methods of the study. The participants of the study were 10 healthy males, aged 19-23 years; height $-177.8 \pm 5.8$; weight $-78.2 \pm 6.1$, body fat $-7.5 \%$ (body fat mass $-5.6 \mathrm{~kg}$ ). The participants of the study were seated in isokinetic dynamometer (Biodex Medical System $P R O$ 3). The type of concentric contraction is automatically established by the system exercising in isokinetic regimen. We tested the average power. The control measurement was performed before the load, after $10 \mathrm{~min}$, $30 \mathrm{~min}, 60 \mathrm{~min}$ and $24 \mathrm{~h}$ after the load; the concentric load was 50 leg extensions and flexions at the knee joint at the fixed $180^{\circ} / \mathrm{s}$ speed. The force was tested in different conditions of thigh quadriceps femoris muscle strain. During electrical stimulation the leg was fixed at different angles of knee joint (they were $90^{\circ}$ and $135^{\circ}$ - the greater the angle, the less the length of the muscle. Quadriceps muscle was stimulated at different frequencies of 20 (low P 20) and 100 (very high P 100) Hz. Control measuring was made before concentric load, after $20 \mathrm{~min}, 70 \mathrm{~min}$ and $24 \mathrm{~h}$ after the load. The maximal voluntary contraction force was also registered before the concentric load, after $20 \mathrm{~min}, 70 \mathrm{~min}$ and $24 \mathrm{~h}$ after the load. Before and after muscle heating and after the concentric load we measured muscle temperature with a needle thermometer.

We established average power of warmed muscle during the leg extension in the knee joint at the fixed $180^{\circ} / \mathrm{s}$ speed to be significantly higher $(\mathrm{p}<0.05)$, compared to the usual temperature. The maximal voluntary contraction force also was significantly higher of warmed muscle $(p<0.05)$. We found that during testing fatigue index of average power for men's knee extensors was the highest in the case of warmed extensors and extensors at their usual temperature - during contractions $41-50$ respectively. There was a significant change in the inner muscle temperature after muscle warming $\left(39.5 \pm 0.2^{\circ} \mathrm{C}\right)$ for $45 \min (\mathrm{p}<0.001)$, compared to the initial (prior to warming $36.9 \pm 0.1^{\circ} \mathrm{C}$ ) values. After performing the concentric load there was a significant increase in temperature $(\mathrm{p}<0.05)\left(40.1 \pm 0,1^{\circ} \mathrm{C}\right)$.

The evidence obtained in this study showed that muscle warming increased maximal voluntary contraction force and muscle contraction power in men's knee extensors, but did not cause any changes in the rate of muscle fatigue performing concentric exercise (50 leg extensions-flexions) at the average $\left(180^{\circ} / \mathrm{s}\right)$ speed.
\end{abstract}

Keywords: muscle heating, muscle power, muscle fatigue, concentric exercise.

Gauta 2009 m. sausio 26 d.

Received on January 26, 2009

Priimta 2009 m. gegužès 6 d.

Accepted on May 6, 2009
Irina Ramanauskiené

Kauno technologijos universitetas

(Kaunas University of Technology)

Donelaičio g. 73, Lt-44248 Kaunas

Lietuva (Lithuania)

Tel +370 37457128

E-mail irina.ramanauskiene@ktu.lt 